\title{
Acute Toxicity Effect of Bonny Light Crude Oil on Sarotherodon melanotheron (Black Chin Tilapia)
}

\author{
${ }^{1}$ Seiyaboh, E.I., Ogamba, E.N., ${ }^{2}$ Utibe, D.I. and Dike, M. \\ ${ }^{I}$ Department of Biological Sciences, Faculty of Science, Niger Delta University, Wilberforce Island, Yenagoa, \\ Bayelsa State. \\ ${ }^{2}$ Department of Animal \& Environmental Biology, Faculty of Science, University of Port Harcourt, Rivers \\ State.
}

\begin{abstract}
The effect of the toxicity of crude oil were investigated in the laboratory using Bonny light crude oil and Sarotherodon melanotheron species from brackish water collected at Eagles Island, Port-Harcourt, Rivers State. Triplicates of 0.01(ppm), 0.005(ppm), 0.01(ppm) and 0.02( water were made in aquaria where Sarotherodon melanotheron species were kept. Soluble water fraction (SWF) of Bonny light crude oil were total hydrocarbon $0.30 \pm 0.02$, dissolved oxygen (DO) $9.50 \pm 0.01$, biological oxygen

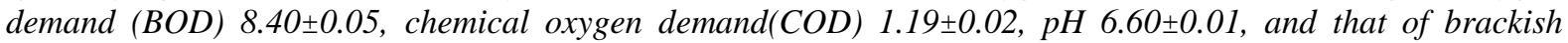
water were dissolved oxygen (DO) 2.03 \pm 2.43 . biological oxygen demand (BOD) 1.09 \pm 1.69 , Lethal concentration of crude oil on the fish samples $\left(L C_{50}\right)$ was $0.01(\mathrm{ppm})$. Bonny light crude oil is toxic to Sarotherodon melanotheron and consequently to the environment.
\end{abstract}

\section{Introduction}

Sarotherodon melanotheron (Black chin Tilapia) is a pale variable (light blue, orange, golden yellow) cichlid whose common name refers to the dark pigmentation usually (but not always) concentrated on the underside of the head (the chin) in the adult animals. Melanin pigmentation is usually present on the posterior edge of the gill and on the tips of the soft dorsal rays. Irregular bars, spots on the body are also typical. The mouth is small and filled with up to several teeth arranged in 3-6 rows (Trewevas 1983).

Sexual dimorphism is minimal in the black chin tilapia (Trewevas 1983). Although the head of adult males are usually slightly larger than those of female and some males also have some gold coloration on their opercula. Sarotherodon melanotheron is similar in appearance to other tilapia fish species and to many cichlids in general. Several of these species can be found as co-occurring non-natives in locations where Sarotherodon melanotheron has become established. The presence and location of dark coloration on or around the chin aid in species identification.

Regional occurrences of Sarotherodon melanotheron is a bottom associated species inhabiting fresh to brackish water where it occurs. It is a tropical West African native, occurring from Senegal to Zaire and Southern Cameroon (Trewevas 1983, Robins, et. al, 1991). The species is common in quite muddy backwater habitats where aquatic vegetation is abundant ( Jennings and William, 1992). Outside of its native range, black chin tilapia has been introduced to several countries across Asia, North America, and Europe.

Age, size, lifespan of Sarotherodon melanotheron (Black chin) tilapia have been reported to reach $28 \mathrm{~cm}$ standard length (SL) (Olaosebikan and Raji, 1998). Within a seasonally impounded mangrove ecosystem, Faunce, (2000), personally reported that black chin tilapia were dominant fish species by weight. In the reproduction of Sarotherodon melanotheron spawning occurs year round, but activity decline in periods of heavy rainfall (Trewevas, 1983). Spawning has been observed from March to November. Fuance, (2000) observed spawning activity peaks in April and May; females will aggressively defend nest sites while males are mouth-brooding (Jennngs and Williams, 1992).

Trewevas (1983) also indicated that Sarotherodon melanotheron can actively achieve sexual maturity at a very small body size, a trait which is an adaptive advantage for an opportunistic invasive species. Females produce a clutch of approximately 50 orange eggs that vary from 1.5-4 $\mathrm{mm}$ in diameter depending on the size of the female. Incubation within the buccal cavity ("mouth brooding") by the male ranges from 6-22.

Black chin tilapia inhabits estuarine habitat such as mangrove marshes, and travel freely between fresh and saltwater environments (Trewevas, 1983).

Nigeria can be classified as a semi arid country with abundant resources, but its precious resources are not managed properly. Environmental pollution caused by industrial development, technology and formal settlements threaten many fresh and marine ecosystems. Not only does environmental pollution cause a decrease in water quality, but subsequently affects all living organisms in that system. It is therefore necessary not only to identify and manage this pollution source but also to monitor their effect on the health of aquatic ecosystem. 
Fishes are relatively sensitive to changes in the environment. Fish health may thus reflect, and be a good indication of the health status of a specific aquatic ecosystem. Early toxicity of pollution may however be evident on cellular or tissue level before significant changes can be identified in fish behavior or external appearance.

Amongst all the different ways in which the industrialized world's use of energy can damage the natural environment, the most vivid for many people may be oil spill. On seemingly regular bases, our newspapers and televisions screens are filled with pictures of tankers spilling crude oil (also known as petroleum). While those of oil spill may be the most publicized, accidental spills from tankers account for only $20 \%$ of the crude oil discharged into the world ocean each year, the remaining $80 \%$ is largely as a result of routine oil tanker operations. There are possible methods of reducing the amount of crude oil released into the ocean each year, but as long as vast amount of oil is routinely transported by sea there will be some amount of unavoidable spillage over the years

Oil discharged into the marine environment will be degraded by physical and chemical processes. Initially, an oil spill will spread quickly across the sea surface, break up into series of "windows" parallel to the direction of the prevailing wind. Evaporation of the oil occurs rapidly, with the volatile component evaporating off within $24 \mathrm{hrs}$; light crude oil spills can lose about $50 \%$ of its volume within a matter of hours. The remaining heavier fractions of the oil will be dispersed in the water as droplets, which will eventually be broken down by bacteria and other microorganism. In some cases water in oil emulsion will form, creating what is known as "chocolate mousses" at the surface. The rate at which emulsion occur is determined by the weather, sea state, temperature, and oil type.

At sea, oil pollution is mostly damaging to surface living animals particularly sea birds, but also marine animals and reptiles. The plumage of sea birds is damaged by oil and they may also ingest oil in an attempt to clean themselves. On shore, certain habitats are both vulnerable and sensitive to oil pollution, this include salt marshes, corals and mangroves. Oil pollution can be very damaging to coastal fish farm (particularly salmon cages and oyster racks) and to coastal amenities such as beaches and mariners.

Oil pollution due to exploration and production on land can also be very damaging to the environment. In most cases, oil pollution is due to poor engineering and management, for example in the Niger Delta region of Nigeria, poorly constructed and maintained pipeline laid across the surface of agricultural lands regularly leak; attempts to burn off the residue often leaves a lifeless crust of the earth up to $2 \mathrm{~m}$ ( $6 \mathrm{ft}$ ) deep, rendering the land unusable for the foreseeable future. The effect of such oil pollution will therefore be apparent for many decades to come.

A number of scientific studies have shown that the degraded marine environment which has resulted from crude oil pollution can be recovered from acute and short term effect if given appropriate time and condition for healthy biological communities to re-establish in the polluted area.

\section{Materials And Methods}

[1]Study Area

The study area is Eagles Island in Rivers State and lies between longitude $6^{0} 59^{1}$ to $6^{0} 58^{1} \mathrm{E}$ and latitude $4^{0} 46^{1}$ to $4^{0} 48^{1} \mathrm{~N}$. The tide amplitudes between $1.5 \mathrm{~m}$ to $2 \mathrm{~m}$ in normal tide and water level increases and decreases depending on lunar cycle. The river is characterized by high sea water inflow and low freshwater input from adjoining mangrove swamp forest and municipal sewers within the Diobu Area of Port Harcout. The influence of sea water is more noticed at high tide but at low water tide the effect is reduced at Elechi creek when fresh water input dominates the area. The mean annual rainfall is estimated to be about 2, 405mm (Gobo, 1988), the area has mixed vegetative mangrove assemblages and the associated species include; Rhizophorus racemosa, R. mangle, Avicenia afrincana, Phoenix reheats and Nipa fructican. Others are Dalbergia sp, Drepanocarpies sp. etc.

\section{[2]Collection Of Samples}

Fry of Sarotherodon melanotheron were used for the experiment. This is due to the more sensitive nature of juveniles to adult for toxicity test. They were obtained from Eagle Island in Port Harcourt and transported in open plastic buckets to the laboratory. The samples were left to acclimatize to laboratory conditions at room temperature for a period of 96 hours. Sample of Bonny light crude oil was collected from shell pipe line Igwuruta, Port-harcout using 10 liters white gallons well corked and kept in the dark to avoid loss of any volatile components and reaction with light. 2.0 liters brackish water was collected using gallon; the gallon was dipped inside the river until it was brim filled with brackish water.

\section{[3]Procedure For 96 Hour Acute Toxicity Tests}

The acute toxicity test used was as described by SMEWW, 1982. 10 test fish each were selected and put into 4 different concentrations which had 2 replicates each. The ten (10) fishes each were transferred to the 
test holding tanks containing toxicants (in this case Bonny light crude oil), all at the same time. Death of fish was assumed to occur when it lay motionless at the bottom and show no evidence of shaking its tall. Indication of hypersensitivity stress or abnormal behavior in the test fish were noted as they are generally forerunners of death. At the end of the 96 hours study period, the number of fish living and death in each of the test series replicates and controls were recorded. Various volumes of crude oil was added to different volumes of brackish water to make four concentration $-0.01 \mathrm{ml}$ of crude oil was added to $1000 \mathrm{ml}$ of brackish water to make 0.01 concentration, $0.05 \mathrm{ml}$ of crude oil was added to $1000 \mathrm{ml}$ of brackish water to make 0.05 concentration, $0.10 \mathrm{ml}$ of crude oil was added to $1000 \mathrm{ml}$ of brackish water to make 0.10 concentration and finally $0.2 \mathrm{ml}$ of crude oil added to $1000 \mathrm{ml}$ of brackish water to make 0.2 concentration.

\section{[4]Physicochemical Parameter Of Water}

Some physiochemical parameters such as dissolved oxygen (DO), temperature, $\mathrm{pH}$, salinity, conductivity, turbidity and biological oxygen demand (BOD) were measured using Horiba probe. Measurements were taken before and after the experiment. The measurements were done by immersing the meter probe into the water body and taking the reading after being stable.

\section{Results And Discussion}

The result for the acute toxicity test of bonny light crude oil on Sarotherodon melanotheron is presented in Table 1. The physic-chemical characteristics of water and crude oil are presented in Table 2. The physic-chemical characteristics of water soluble fractions (WSF) OF bonny light crude oil are presented in Table 3.

It was observed from this study that with the highest concentration of bonny light crude oil $(0.02 \%)$ all the fishes died; this is an indication that $0.02 \%$ of bonny light crude oil is the most toxic (100\% mortality rate). $\mathrm{Lc}_{50}$ which is the lethal concentration was observed in this study to be from $0.01 \%$.

Bonny light crude oil is toxic to Sarotherodon melanotheron. Toxicity was observed to be directly proportional to mortality rate. The investigation revealed that SWF of bonny light crude oil was: Total hydrocarbon $0.30 \pm 0.02$, dissolved oxygen (DO) $9.50 \pm 0.01$, biological oxygen demand (BOD) $8.40 \pm 0.05$, chemical oxygen demand(COD) $1.19 \pm 0.02, \mathrm{pH} 6.60 \pm 0.01$ and it was found to be similar to the findings of Akaninwor, et. al.2006. The experimental fish Sarotherodon melanotheron died at a lethal concentration $\left(\mathrm{Lc}_{50}\right)$ similar to the findings of Ayoola and Alajabo 2012 who reported that the lethal concentration $\mathrm{Lc}_{50}$ that caused $50 \%$ mortality was approximately $1.12 \mathrm{mg} / \mathrm{l}$ of engine oil on Sarotherodon melanotheron

\section{Conclusion}

Bonny light crude oil is toxic to marine organisms as depicted by its lethal effect on Sarotherodon melanotheron. However, with adequate production and transportation of crude oil, spills and its adverse effects on living organisms can be averted.

Table 1 Acute Toxicity Test of Bonny Light Crude Oil on Sarotherodon melanotheron

\begin{tabular}{|c|c|c|c|c|c|c|c|}
\hline $\begin{array}{c}\text { Concentrations } \\
(\%)\end{array}$ & $\begin{array}{l}\text { Vol. of crude } \\
\text { oil } \\
\text { (ml) }\end{array}$ & Day 1 & Day 2 & Day 3 & Day 4 & $\begin{array}{c}\text { Total } \\
\text { Mortality } \\
(\%)\end{array}$ & Mean (\%) \\
\hline Control A & $\begin{array}{ll}\text { Nil } & \text { A } \\
& \text { B } \\
& \text { C }\end{array}$ & $\begin{array}{l}- \\
- \\
-\end{array}$ & $\begin{array}{l}- \\
- \\
-\end{array}$ & $\begin{array}{l}- \\
- \\
-\end{array}$ & $\begin{array}{l}- \\
- \\
-\end{array}$ & $\begin{array}{ll}- \\
- \\
-\end{array}$ & \\
\hline 0.001 & $\begin{array}{ll}0.01 & \mathrm{~A} \\
& \mathrm{~B} \\
& \mathrm{C}\end{array}$ & $\begin{array}{l}- \\
- \\
-\end{array}$ & $\begin{array}{l}- \\
- \\
-\end{array}$ & $\begin{array}{l}1 \\
1 \\
1\end{array}$ & $\begin{array}{l}- \\
2 \\
1\end{array}$ & $\begin{array}{l}1=10 \% \\
3=30 \% \\
2=20 \%\end{array}$ & $20 \%$ \\
\hline 0.005 & $\begin{array}{ll}0.05 & \mathrm{~A} \\
& \mathrm{~B} \\
& \mathrm{C} \\
\end{array}$ & $\begin{array}{l}1 \\
- \\
1\end{array}$ & $\begin{array}{l}1 \\
1 \\
-\end{array}$ & $\begin{array}{l}2 \\
1 \\
2\end{array}$ & $\begin{array}{l}- \\
2 \\
-\end{array}$ & $\begin{array}{l}4=40 \% \\
4=40 \% \\
3=30 \%\end{array}$ & $38.7 \%$ \\
\hline 0.01 & $\begin{array}{ll}0.10 & \mathrm{~A} \\
& \mathrm{~B} \\
& \mathrm{C}\end{array}$ & $\begin{array}{l}2 \\
1 \\
1\end{array}$ & $\begin{array}{l}2 \\
1 \\
2\end{array}$ & $\begin{array}{l}1 \\
3 \\
2\end{array}$ & $\begin{array}{l}3 \\
2 \\
3\end{array}$ & $\begin{array}{l}8=80 \% \\
7=70 \% \\
8=80 \%\end{array}$ & $76.7 \%$ \\
\hline 0.02 & $\begin{array}{ll}0.2 & \mathrm{~A} \\
& \mathrm{~B} \\
& \mathrm{C} \\
\end{array}$ & $\begin{array}{l}2 \\
3 \\
2 \\
\end{array}$ & $\begin{array}{l}3 \\
5 \\
4 \\
\end{array}$ & $\begin{array}{l}4 \\
2 \\
4 \\
\end{array}$ & $\begin{array}{l}1 \\
\text { Ended } \\
1\end{array}$ & $\begin{array}{l}10=100 \% \\
10=100 \% \\
10=100 \%\end{array}$ & $100 \%$ \\
\hline
\end{tabular}


Table 2 Physico-Chemical Characteristics of Water and Crude Oil

\begin{tabular}{|c|c|c|c|c|c|}
\hline $\begin{array}{c}\text { Concetrations } \\
(\boldsymbol{\%})\end{array}$ & Temp $\left({ }^{\mathbf{O}} \mathbf{C}\right)$ & $\mathbf{p H}$ & $\begin{array}{c}\text { Conductivity } \\
\boldsymbol{\mu S} / \mathbf{c m}\end{array}$ & Turbidity NTU & Salinity mg/l \\
\hline $\mathrm{H}_{2} \mathrm{O}$ & 26.8 & 7.5 & 18000 & 3 & 10.7 \\
\hline $\begin{array}{c}\mathrm{H}_{2} 0+\text { Crude } \\
0.001\end{array}$ & 26.8 & 7.4 & 18300 & 12 & 10.7 \\
\hline $\begin{array}{c}\mathrm{H}_{2} 0+\text { Crude } \\
0.005\end{array}$ & 26.9 & 7.3 & 18000 & 18 & 10.9 \\
\hline $\begin{array}{c}\mathrm{H}_{2} 0+\text { Crude } \\
0.01\end{array}$ & 26.9 & 7.3 & 18300 & 32 & 10.9 \\
\hline $\begin{array}{c}\mathrm{H}_{2} 0+\text { Crude } \\
0.02\end{array}$ & 27.0 & 7.2 & & \\
\hline
\end{tabular}

Table 3 Physico-chemical characteristics of water soluble fractions (WSF) OF bonny light crude oil

\begin{tabular}{|c|c|c|c|c|c|}
\hline Samples & $\begin{array}{c}\text { Total Hydrocarbon } \\
(\mathbf{p p m})\end{array}$ & DO & BOD & COD \\
\hline $\begin{array}{c}\text { Brackish } \\
\text { Water }\end{array}$ & - & $2.43 \pm 2.03$ & $1.69 \pm 1.09$ & - & - \\
\hline $\begin{array}{c}\text { Bony Light } \\
\text { (WSF) }\end{array}$ & $0.30 \pm 0.02$ & $9.50 \pm 0.01$ & $6.40 \pm 0.05$ & $1.19 \pm 0.02$ & $6.6 \pm 0.01$ \\
\hline
\end{tabular}

\section{References}

[1]. Ayoola, S.O. and Alajabo, O.T. (2012) Acute Toxicity and Histopathological Effect of Engine Oil on Sarotherodon melanotheron (Black Jaw Tilapia). American-Eurasian Journal of Toxicoloogical Sciences 4 (10 48-55, 2012.

[2]. Fuance, C.H. (2000) Reproduction of Black chin Tilapia (Sarotherodon melanotheron) within the impounded mangrove ecosystem in East-central Florida. Environ. Biol. Fishe.s 57: pp 353-361.

[3]. Jennings, D.P. and Williams, J.D. (1992) Factors influencing the distribution of Black chin Tilapia (Sarotherodon melanotheron) in the Indian River system. Florida Northeast Gulf Science. 12: pp 111-117.

[4]. Robins, C.R., Bailey, R.M., Bond, C.E., Brooker, J.R., Lachner, E.A., Lee, R.N. and Scott, W.B. (1991) World Fishes important to North America exclusive of species from the continental waters of the United States and Canada. Am. Fish. Soc. Spec. Publ. 21: p243.

[5]. Olaosebikan, B.D. and Raji, A. (1998) Field Guide to Nigeria Fresh Water Fishes. Federal College of Freshwater Fisheries Technology, New Bussa, Nigeria. P106.

[6]. Trewaves, E. (1983) Tilapine Fishes of the Genera Sarotherodon melanotheron, Orechromis and Danakilia. British Museum of Natural History Publ. No 878. Comstock Publishing Associate, Ithaca, New York, p583.

[7]. SMEWW (Standard Methods for the Examination of Water and Wastewater) 1982. Publ. D1067-70. 